\begin{tabular}{|l|l|l|l|l|l|} 
J. Tek. Ling & Vol.11 & No.2 & Hal. 189 - 195 & Jakarta, Mei 2010 & ISSN 1441-318X \\
\hline
\end{tabular}

\title{
PENENTUAN JENIS VEGETASI LOKAL UNTUK PERLINDUNGAN TEBING SUNGAI SIAK DENGAN DESAIN EKO - ENGINEERING TANPA TURAP
}

\author{
Euthalia Hanggari Sittadewi \\ Peneliti di Pusat Teknologi Sumberdaya Lahan, \\ Kawasan dan Mitigasi Bencana \\ Badan Pengkajian dan Penerapan Teknologi
}

\begin{abstract}
Eco - engineering without civil's construction design for the Siak riverside's protection can be applied at the part of river has riverside's weak damaged. The riverside's protection system with eco - engineering without civil's construction as the effort to make stronger the riverside with vegetation components. The used of local vegetation is the best choice for eco-engineering system. The identification of vegetation on the Siak river's corridor as long as desa Merempan Hilir to choose the plants to make the eco-engineering without civil construction's design has been done. Some kind of plants have been choosen i.e : rumput teki (Cyperus rotundus), rumput kumpai (Hymenachne acutigluma) rumput akar wangi (Vetiveria zizanioides), karangkunan (Ipomea carnea), bambu kuning (Bambusa vulgaris), pandan (Pandanus, sp), bintaro (Cerbera manghas), rengas (Gluta renghas), kempas (Koompassia malaccensis), jawi - jawi (Ficus, sp) and meranti (Shorea, sp).
\end{abstract}

Key words : desain eko - engineering tanpa turap, perlindungan tebing, tanaman lokal

\section{PENDAHULUAN}

\subsection{Latar Belakang}

Sungai dengan segala karakteristik alamiahnya telah membentuk komposisi yang paling stabil dibandingkan dengan komposisi buatan, sehingga perubahan terhadap karakteristik alamiah akan menurunkan kemampuan sungai untuk menjaga keseimbangannya. Perubahan karakteristik sungai karena adanya bangunan teknis pertama akan direspon oleh sungai dengan berbagai perubahan karakteristik yang tidak hanya terjadi di daerah yang diubah namun juga terjadi di bagian lainnya dialur sungai yang bersangkutan.

Konsep keseimbangan adalah upaya yang perlu dilakukan dalam penanganan sungai sehingga tidak mengganggu keseimbangan yang sudah ada. Justru keseimbangan sungai tersebut perlu dimanfaatkan dalam rangka pengembangan sekaligus konservasi. Konsep penyeimbangan ini dapat diterapkan dalam upaya mengatasi longsoran tebing yaitu dengan penanaman vegetasi yang cocok di sepanjang alur sungai yang tererosi. Dengan mengaktifkan kembali komponen ekologi vegetasi alamiah, maka baik longsor, banjir di hilir, mekanisme outflow - inflow, kekeringan musim kemarau dan lainnya dapat dihindarkan.

Dengan keberlangsungan ekosistem maka sungai dan bantarannya diharapkan dapat memberikan manfaatnya secara maksimal untuk kesejahteraan makhluk hidup flora dan fauna serta kesejahteraan manusia secara terus menerus. Semakin alamiah kondisi 
sungai dan bantarannya maka semakin banyak manfaat yang diperoleh, sedang semakin rusak kondisi sungai maka semakin banyak memberi masalah. Bantaran Sungai Siak saat ini telah mengalami kerusakan yang ditandai dengan semakin melebarnya badan sungai. Tingginya aktivitas transportasi pelayaran di Sungai Siak, menyebabkan tingginya tingkat erosi pada tebing sungai yang dapat meningkatkan sedimentasi. Lahan di bantaran sungai termasuk vegetasi diatasnya hilang tergerus gelombang antara lain disebabkan oleh lalu lintas kapal bertonasi tinggi, hilangnya green belt di pinggiran sungai dan adanya perkembangan yang pesat di DAS Siak. ${ }^{1)}$

Untuk bagian sungai yang mengalami kerusakan tebing ringan, penguatan tebingnya tidak dibutuhkan konstruksi sipil atau dengan kata lain dapat diatasi dengan desain eko - engineering tanpa turap. Sistem perlindungan tebing secara ekoengineering dimaksudkan sebagai usaha sejauh mungkin dengan menggunakan komponen vegetasi di sepanjang bantaran sungai untuk menanggulangi longsoran dan erosi tebing sungai serta kerusakan bantaran sungai lainnya. Penggunaan tanaman lokal adalah yang paling tepat untuk pelaksanaan sistem eko-engineering ini. Tanaman setempat yang ada di sepanjang alur Sungai Siak dapat diidentifikasi dan dipilih yang paling sesuai untuk keperluan lindungan tebing di tempat tersebut, karena jenis tanaman di suatu tempat dipengaruhi oleh faktor tanah, dinamika aliran air, penyinaran matahari, serta temperatur dan iklim mikro lainnya.

Dengan demikian, agar dapat berfungsi secara maksimal, beberapa persyaratan dalam memilih vegetasi untuk desain penataan bantaran Sungai Siak harus memenuhi persyaratan sbb :

Menggunakan jenis tanaman lokal/ setempat

- Dapat berfungsi sebagai penangkal erosi banjir akibat hujan

- Dapat mempertahankan fungsi ekologi bantaran sungai ${ }^{2}$.

Dari hasil identifikasi vegetasi di pinggir
Sungai Siak sepanjang desa Merempan Hilir, terdapat beberapa tanaman jenis rumput - rumputan, kangkung - kangkungan dan pohon - pohonan yang dapat dipilih untuk penguatan tebing dengan desain eco - engineering tanpa turap. Beberapa jenis rumput - rumputan yang dimaksud adalah rumput teki (Cyperus rotundus), rumput kumpai (Hymenachne acutigluma) rumput akar wangi (Vetiveria zizanioides), dari jenis kangkung - kangkungan adalah karangkunan (Ipomea carnea). Selain itu dapat juga digunakan bambu kuning (Bambusa vulgaris) dan pandan (Pandanus, sp). Sedangkan jenis pohon - pohonan antara lain bintaro (Cerbera manghas), rengas (Gluta renghas), kempas (Koompassia malaccensis), jawi - jawi (Ficus, sp) dan meranti (Shorea, sp).

\subsection{Tujuan}

Penelitian ini bertujuan untuk :

a. Mengetahui jenis vegetasi lokal di pinggir Sungai Siak khususnya sepanjang Desa Merempan Hilir.

b. Mendapatkan jenis vegetasi lokal terpilih dari pinggir Sungai Siak untuk desain eko - engineering tanpa turap.

c. Mendapatkan desain eko-engineering tanpa turap untuk perlindungan tebing Sungai Siak

\section{METODOLOGI}

\subsection{Lokasi dan Waktu Penelitian}

Lokasi penelitian dipilih berdasarkan hasil survei terdahulu yang telah mengidentifikasi tingkat kerusakan tebing Sungai Siak. Koridor Sungai Siak yang mempunyai tebing dengan tingkat kerusakan yang tinggi ditentukan sebagai lokasi penelitian. Lokasi penelitian adalah : sepanjang Koridor Sungai Siak, Desa Merempan Hilir. Identifikasi dilakukan di sebelah kanan dan kiri Sungai Siak kurang 
lebih sepanjang $10 \mathrm{~km}$.

- Waktu Penelitian : November 2008

\subsection{Metode Penelitian}

- Melakukan identifikasi tanaman tanaman di desa Merempan Hilir yang terletak di pinggir Sungai Siak

- Pengamatan dan pengambilan contoh tanaman dilakukan dengan menggunakan transportasi perahu.

- Identifikasi dilakukan dengan cara pengamatan langsung dan pengambilan contoh daun. Semua contoh baik yang telah diketahui nama lokal atau nama daerahnya maupun yang belum, diidentifikasi dengan bantuan literatur.

Identifikasi dilakukan sampai penentuan species dengan nama latin dan nama daerah (nama lokal).

- Memilih jenis tanaman lokal untuk penerapan desain eko - engineering tanpa turap. Jenis vegetasi untuk perlindungan tebing yang paling tepat adalah dengan menggunakan tanaman - tanaman lokal (setempat). Namun tidak semua vegetasi di pinggir sungai cocok untuk berbagai tempat, karena jenis tanaman di statu tempat dipengaruhi oleh factor tanah, dinamika aliran air, penyinaran matahari, serta temperatur dan iklim mikro lainnya. Oleh sebab itu perlu dipilih jenis vegetasi yang cocok untuk daerah yang akan dilindungi.

- Memilih alternatif desain perlindungan tebing dengan sistem eko-engineering tanpa turap.

\section{HASIL DAN PEMBAHASAN}

\subsection{Hasil Identifikasi Jenis Tanaman di Pinggir Sungai Siak, Desa Merempan Hilir}

Dari hasil inventarisasi jenis tanaman di pinggir Sungai Siak, Desa Merempan Hilir tercatat lebih kurang 24 jenis tanaman yang termasuk dalam jenis pohon, perdu, rumput rumputan dan buah - buahan. $\mathrm{Ke}-22$ jenis tanaman tersebut adalah sbb :

a. Jenis rumput

\begin{tabular}{|l|l|l|}
\hline No & \multicolumn{1}{|c|}{ Nama Lokal } & \multicolumn{1}{c|}{ Nama Latin } \\
\hline 1 & Rumput teki & Cyperus rotundus \\
\hline 2 & Rumput kumpai & Hymenachne acutigluma \\
\hline 3 & Rumput akar wangi & Vetiveria zianioides \\
\hline 4 & Alang - alang & Imperata cylindrica \\
\hline
\end{tabular}

b. Jenis bambu, kangkung - kangkungan, pandan dan kelapa

\begin{tabular}{|l|l|l|}
\hline No & \multicolumn{1}{|c|}{ Nama Lokal } & \multicolumn{1}{c|}{ Nama Latin } \\
\hline 1 & Bambu kuning & Bambussa, sp \\
\hline 2 & Bambu kasap & Pogonatherium \\
\hline 3 & Pandan & Pandanus, $s p$ \\
\hline 4 & Karangkunan & Ipomea carnea \\
\hline 5 & Kelapa sawit & Elaeis guineensis \\
\hline 6 & Rumbia & Nypha fruticans \\
\hline
\end{tabular}

\begin{tabular}{|l|l|l|}
\hline No & Nama Lokal & Nama Latin \\
\hline 1 & Akasia & Acasia, $s p$ \\
\hline 2 JenisaRppbayau & Acanthus ilicifolium, $L$ \\
\hline 3 & Binjai & Mangifera caesia \\
\hline 4 & Bintaro & Cerbera manghas \\
\hline 5 & Berembang & Sonneratia, $s p$ \\
\hline 6 & Jawi - jawi & Ficus, $s p$ \\
\hline 7 & Keduduh & Melastoma candidum \\
\hline 8 & Kempas & Koompassia malaccensis \\
\hline 9 & Meranti & Shorea, $s p$ \\
\hline 10 & Putat & Barringtonia spicata \\
\hline 11 & Rengas & Gluta renghas \\
\hline 12 & Waru & Hibiscus tiliaceus L \\
\hline
\end{tabular}

Sumber : Hasil identifikasi, 2008 http://www. selera-kita.n1/latin.htm1 ${ }^{3)}$ Van Steenis, 1975 ${ }^{4}$

Vegetasi pinggir sungai tersebut sangat penting untuk dipertahankan karena mempunyai fungsi ekologi sbb :

1. Sebagai tempat hidup flora dan fauna sungai

2. Sebagai tempat penyelamatan diri fauna sungai ketika banjir

3. Sebagai komponen peneduh sungai sehingga membatasi perkembangan 
tumbuhan air, menjaga suhu air relatif rendah dan stabil, mengurangi laju penguapan air serta membatasi kehilangan kandungan oksigen terlarut (DO)

4. Sebagai komponen penggembur sekaligus pengikat tanah tebing sungai

5. Sebagai pengikat zat hara dalam tanah sehingga mengurangi kehilangan zat hara tanah pinggir sungai akibat pencucian (leaching)

6. Sebagai pemasok bahan makanan bagi fauna berupa daun, buah serta bangunan tumbuhan yang telah tua dan jatuh ke perairan untuk kemudian membusuk2).

\subsection{Penentuan Jenis Tanaman untuk Penerapan Eko - engineering.}

Jenis vegetasi untuk perlindungan tebing yang paling tepat adalah dengan menggunakan tanaman - tanaman lokal (setempat). Dalam hal ini, tidak semua vegetasi di pinggir sungai cocok untuk berbagai tempat, karena jenis tanaman di satu tempat dipengaruhi oleh faktor tanah, dinamika aliran air, penyinaran matahari serta temperatur dan iklim mikro lainnya. Pada umumnya vegetasi yang ada sangat specifik untuk penggal sungai tertentu ${ }^{2}$. Hasil identifikasi tanaman di pinggir Sungai Siak sepanjang Desa Merempan Hilir, yang dapat dipilih untuk penerapan eko - engineering tanpa turap antara lain :

a. Jenis rumput, kangkung kangungan, bambu dan pandan.

Beberapa jenis rumput - rumputan dan kangkung - kangkungan yang dijumpai adalah : rumput teki (Cyperus rotundus), karangkunan (Ipomea carnea), rumput kumpai (Hymenachne acutigluma), rumput akar wangi (Vetiveria zizanioides). Golongan rumput - rumputan dan kangkung - kangkungan tersebut diatas bersifat lentur. Selain jenis tanaman tersebut diatas tanaman yang bersifat lentur yang lain adalah bambu kuning (Bambusa vulgaris), pandan (Pandanus, sp). Tanaman - tanaman yang bersifat lentur tersebut diatas dapat digunakan untuk perlindungan tebing pada kecepatan arus tinggi2)

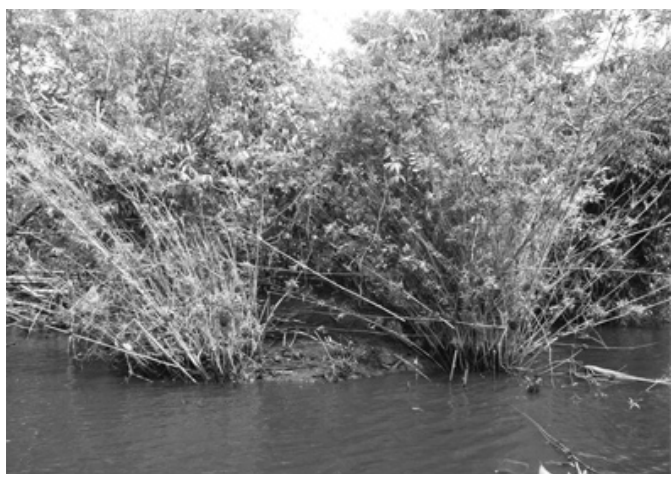

Bambu kuning (Bambusa vulgaris)

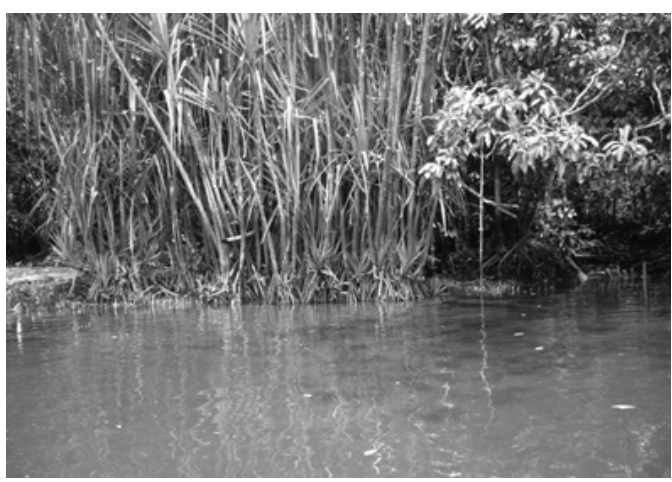

Pandan (Pandanus, $s p$ )

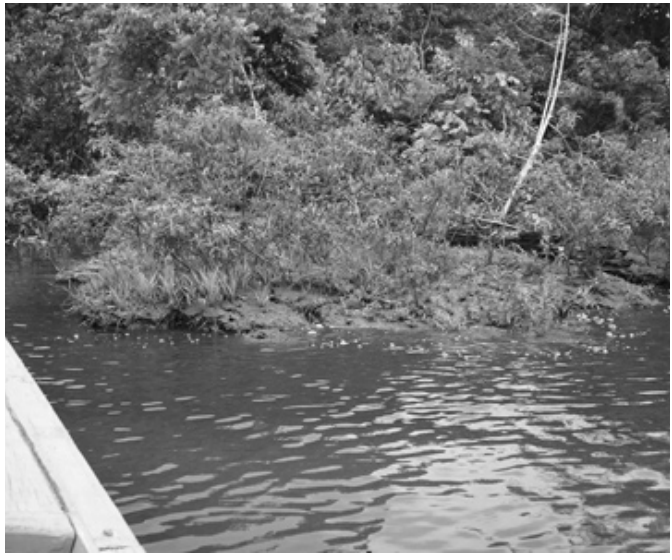

Karangkunan (Ipomea carnea) 


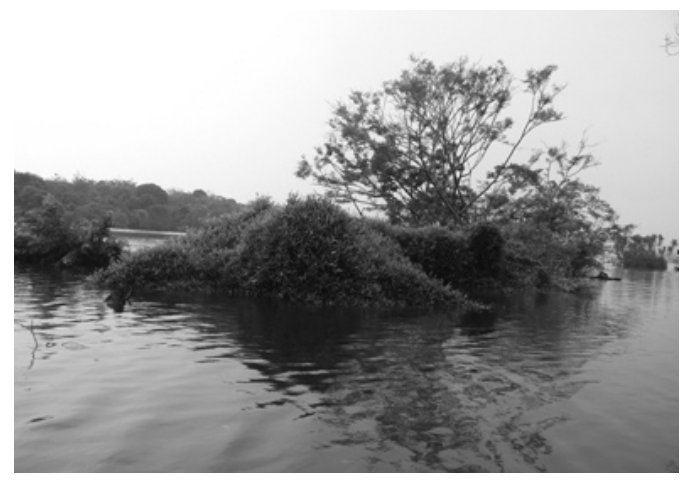

Rumput kumpai (Hymenachne acutigluma)

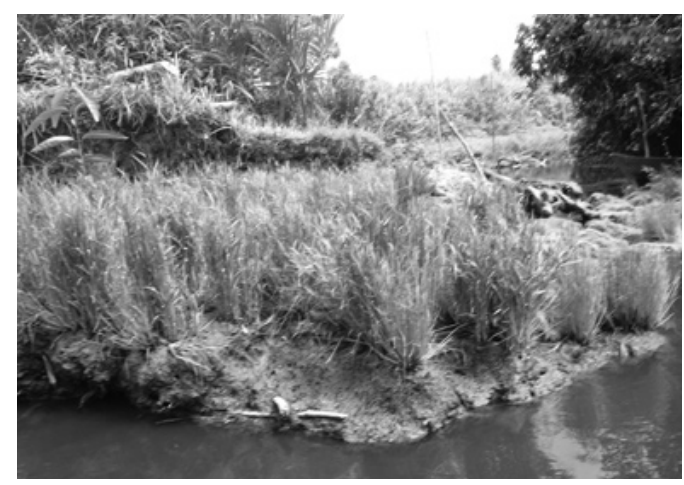

Rumput teki (Cyperus rotundus )

b. Jenis pohon - pohonan

Beberapa jenis pohon - pohonan di pinggir Sungai Siak sepanjang Desa Merempan Hilir yang dapat digunakan sebagai pelindung tebing antara lain : bintaro (Cerbera manghas), rengas (Gluta renghas), kempas (Koompassia malaccensis), jawi - jawi (Ficus, sp), meranti (Shorea, sp).

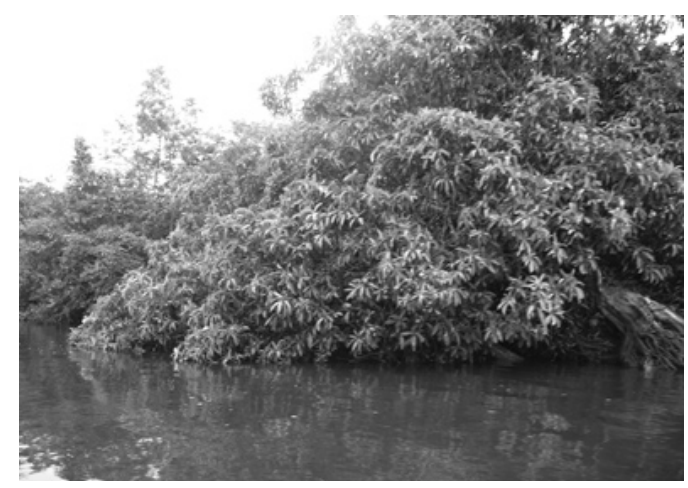

Rengas (Gluta renghas)

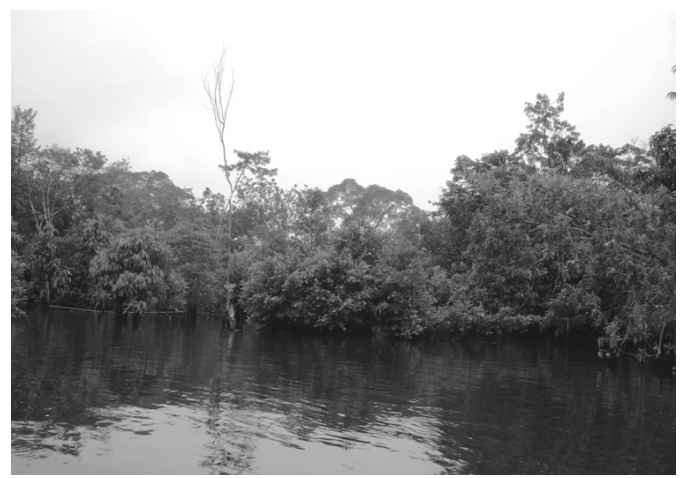

Bintaro (Cerbera manghas)

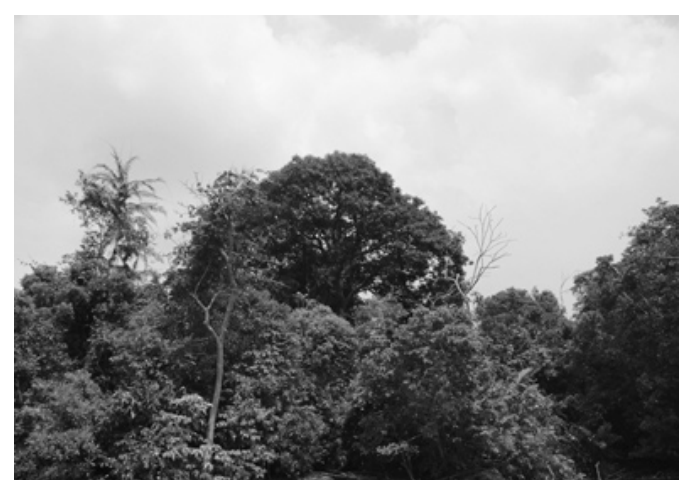

Jawi - jawi (Ficus, sp) dan Meranti (Shorea, sp)

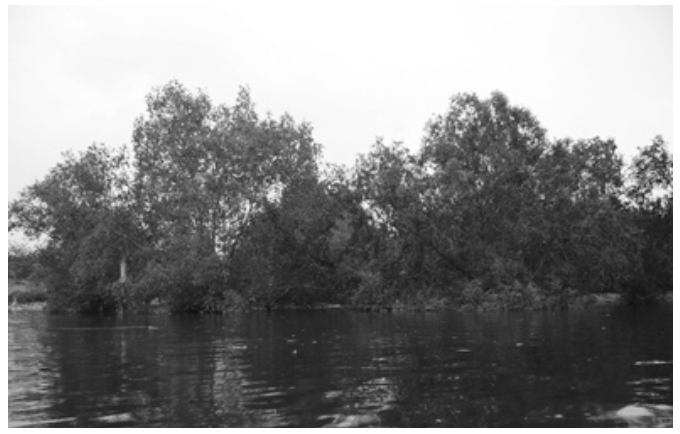

Kempas (Koompassia malaccensis)

\subsection{Beberapa Desain Eko -} engineering tanpa turap

a. Penggunaan vegetasi bambu atau pandan, rumput dan karangkunan untuk perlindungan tebing Sungai Siak

Pada pemilihan jenis vegetasi ini, sangat perlu dipertimbangkan besarnya 
kecepatan air. Seperti telah disebutkan diatas, golongan rumput - rumputan (Fam. Gramineae) dan kangkung-kangkungan (Fam.Convolvulaceae) yang bersifat lentur bisa digunakan untuk perlindungan tebing pada kecepatan arus tinggi, sedang yang sifatnya getas (mudah patah) untuk kecepatan rendah. Pada penanaman vegetasi tersebut, sangat diperlukan perlindungan awal sampai vegetasi tersebut tumbuh dan berakar kuat sebelum terkena banjir dan atau arus yang relatif kuat. Dengan demikian akan sangat baik jika ditanam pada pertengahan musim kemarau atau akhir musim penghujan, sehingga pada musim penghujan berikutnya tanaman sudah kuat menahan energi aliran air. Dari hasil identifikasi, jenis tanaman yang ada di pinggir sungai Siak yang dapat dipilih adalah : rumput vetiver atau rumput akar wangi (Vetiveria zizanioides), rumput kumpai (Hymenachne acitigluma), rumput teki (Cyperus rotundus), karangkungan (Ipomea carnea), bambu kuning (Bambusa vulgaris) dan pandan (Pandanus, sp). Hal ini sesuai dengan hasil penelitian yang dilakukan oleh Budinetro bahwa di Indonesia, tanaman yang dapat digunakan untuk perlindungan tebing antara lain ada 3 jenis yaitu bambu (Bambusa, sp), rumput vetiver (Vetiveria zizanioides) dan karangkungan (Ipomoea carnea) ${ }^{5}$. Akar rumput vetiver tumbuh lebat menancap kebawah, dapat mencapai 3 meter sehingga tidak terjadi perebutan unsur hara dengan tanaman lain, selain itu umurnya panjang dan dapat bertahan puluhan tahun. Karangkungan merupakan tanaman yang dapat tumbuh di segala tempat serta tahan terhadap genangan dan arus air. Bambu, batang berbentuk pipa, mempunyai kekuatan khusus di bagian dalam dan luar batangnya, kekuatan tarik lapis luar dua kali lipat dari bagian dalam dan mempunyai kekuatan tinggi secara aksial dan memiliki sifat lentur, dalam waktu 3-4 bulan dapat mencapai ketinggian maksimum 40 meter ${ }^{2)}$.

Kombinasi konstruksi bambu, rumput vetiver dan karangkungan sesuai untuk lokasi yang mempunyai kondisi dimana kecepatan air saat banjir kurang dari $1,5 \mathrm{~m} /$ $\mathrm{dt}$, air banjir banyak membawa sedimen tersuspensi (banyak membawa lumpur) dan dasar sungai bukan tersusun oleh batu kerikil.

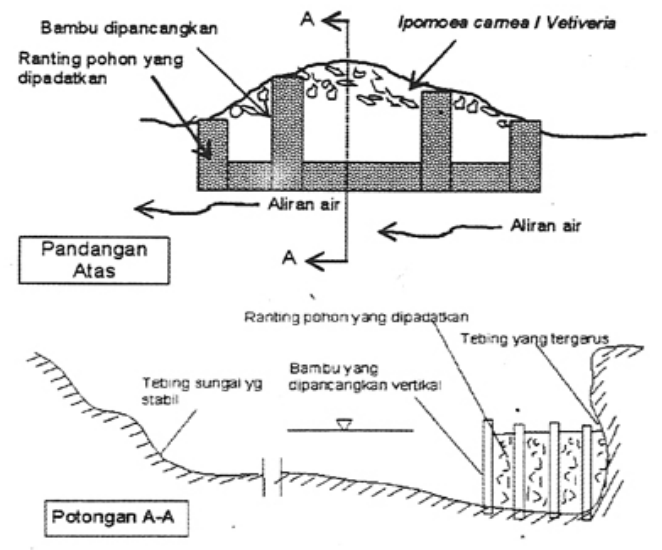

Eko - engineering untuk pengendalian erosi tebing dengan penanaman karangkungan dan rumput vetiver pada endapan baru $(5,2)$.

Cara pemasangannya adalah batang bambu dipancangkan vertikal pada lokasi yang tebingnya mengalami ancaman gerusan, batang melintang - mendatar dipasang dan diikatkan pada batang vertikal sebagai penguat. Diantara baris batang vertikal dimasukkan ranting pohon .

Dengan ini terbentuklah krip poros yang dapat menahan air banjir dan mengikat sedimen. Setelah endapan terbentuk maka karangkungan atau rumput vetiver ditanam. Selanjutnya karangkungan atau rumput retiver akan tumbuh kuat dan tumbuhnya tidak teratur saling tindih dan terkait sehingga dapat mempercepat proses pengendapan. Pada saat batang bambu mulai rapuh dimakan panas dan waktu, rumput vetiver atau karangkungan dan endapan baru pada kaki tebing sungai cukup stabil serta mampu menahan gerusan. Perlindungan tebing dengan eko-engineering dapat menjamin keluar masuknya biota air, amphibi dan biota daratan, sehingga tidak menimbulkan kesulitan bagi biota sungai untuk bermigrasi atau bergerak secara horizontal ${ }^{6}$. 


\section{b. Penggunaan vegetasi pohon - pohonan untuk perlindungan tebing Sungai Siak}

Ada beberapa alternatif dalam penggunaan vegetasi pohon-pohonan untuk perlindungan tebing yaitu :

1. Batang pohon yang tidak teratur: dengan menggunakan pohon tumbang baru dan belum dipotongi, dahan dan rantingnya dapat dipasang pada bagian yang longsor. System perlindungan tebing seperti ini dapat diterapkan di Sungai Siak karena banyak didapatkan pohon - pohonan antara lain, bintaro (Cerbera manghas), kempas (Koompassia malaccensis), jawi - jawi (Ficus, $s p)$, meranti (Shorea, sp). Bagian bawah (akarnya) diletakkan di hulu membujur di sepanjang tebing yang longsor. Pada longsoran yang panjang dapat digunakan sejumlah batang pohon yang dipasang memanjang.

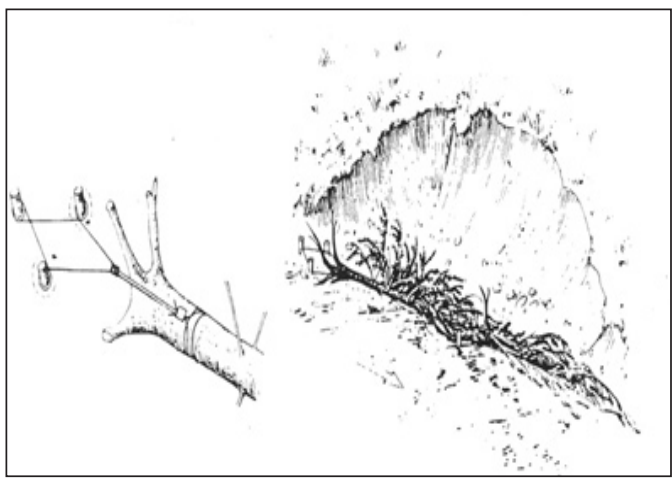

Batang pohon yang tidak teratur (Sumber :Patt et.,1999) ${ }^{6)}$

2. Penanaman tebing : tebing - tebing sungai yang tanpa tumbuhan sebaiknya sesegera mungkin ditanami. Untuk penerapan perlindungan tebing di Sungai Siak dengan sistem penanaman tebing.
Jenis tanaman lokal yang dapat digunakan antara lain bambu (Bambusa, sp). Penanaman bambu dapat dilakukan dengan memilih beberapa jenis bambu yang sesuai dengan lebar dan kedalaman sungai. Untuk Sungai Siak dapat ditanam jenis bambu yang besar. Tanaman di tebing sungai, selain berfungsi sebagai pelindung tebing juga berfungsi sebagai retensi aliran, sehingga kecepatan aliran turun dan banjir di hilir dapat dikurangi (6).

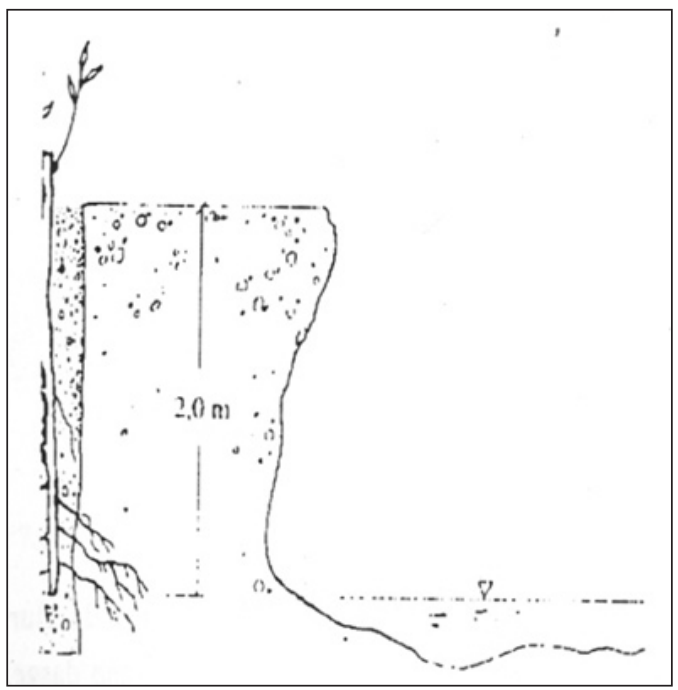

Penanaman tebing dengan bambu (Bambusa, sp)

(Sumber :Patt et.,1999) ${ }^{6)}$

\section{KESIMPULAN}

1. Terdapat lebih kurang 22 jenis tanaman lokal di pinggir Sungai Siak yang sudah teridentifikasi dan dapat dipilih untuk perbaikan perlindungan tebing sungai.

2. Dari golongan rumput - rumputan yang dapat dipilih untuk perlindungan tebing adalah rumput teki (Cyperus rotundus), rumput kumpai (Hymenachne acutigluma) 
dan rumput akar wangi (Vetiveria zizanioides). Dari golongan kangkung - kangkungan adalah karangkunan (Ipomea carnea). Selain itu dapat digunakan pandan (Pandanus, sp) dan bambu kuning (Bambusa vulgaris), Sedangkan dari golongan pohon - pohonan adalah bintaro (Cerbera manghas), rengas (Gluta renghas), kempas (Koompassia malaccensis), jawi - jawi (Ficus, sp) dan meranti (Shorea, sp).

3. Desain eko - engineering tanpa turap dapat diterapkan pada segmen sungai dengan tingkat kerusakan tepi sungai yang tidak terlalu parah. Alternatif desain tersebut antara lain adalah :

- Desain dengan menggunakan vegetasi bambu atau pandan, rumput dan karangkunan

- Desain dengan menggunakan vegetasi pohon - pohonan.

4. Untuk perlindungan tebing pada kecepatan arus tinggi dapat digunakan beberapa tanaman yang bersifat lentur. Tanaman lokal yang dapat digunakan yaitu dari golongan rumput - rumputan seperti rumput teki (Cyperus rotundus), rumput kumpai (Hymenachne acutigluma) rumput akar wangi (Vetiveria zizanioides) dan golongan kangkung - kangkungan yaitu karangkunan (Ipomea carnea).

\section{DAFTAR PUSTAKA}

1 Anonim., 2006. Laporan Akhir Penysunan Pola Pengelolaan Sungai dan Pesisir Terpadu Daerah Aliran Sungai (DAS) Siak. Balitbang Pemerintah Provinsi Riau.

2 Maryono, A.,P. 2005. Eko - Hidraulik. Pembangunan Sungai. Edisi Kedua.

3. http://www.selera-kita.n1/latin.htm1

4. Van Steenis, C.G.G.J cs, 1975. Flora. Untuk Sekolah di Indonesia. Pradnya Paramita, Jakarta.

5. Budinetro, H.S., 2001 : Bio-Engineering pengendali erosi bantaran tebing dan erosi sungai. Proceeding Seminar Nasional Eko-Hidraulik. Asosiasi Eko - Hidraulik Indonesia (ASEHI), Yogyakarta.

6. Noor, Y.R., et.al., 2006. Panduan Pengenalan Mangrove Di Indonesia, Wetland International Indonesia Programme, Bogor, Indonesia 